\title{
Microevolution of Asian Sockeye Salmon Oncorhynchus nerka and its Link to Modern Diversity of Populations
}

\author{
Anastasia M. Khrustaleva ${ }^{1}$, Ekaterina V. Ponomareva ${ }^{2}$, Marya V. Ponomareva ${ }^{2}$, Oksana A. Pilganchuk ${ }^{3}$, and \\ Alexander V. Bugaev ${ }^{3}$
${ }^{1}$ Institute of Gene Biology Russian Academy of Sciences (FSBIS IGB RAS), 119334 Moscow, Vavilova St., 34/5, Russia \\ ${ }^{2}$ M.V. Lomonosov Moscow State University (MSU), 119991 Moscow, GSP-1, Leninskie Gory, Russia \\ ${ }^{3}$ Kamchatka branch of the FSBSI VNIRO (KamchatNIRO), 683000 Petropavlovsk-Kamchatskij, Naberezhnaya St., \\ 18, Russia
}

Keywords: sockeye salmon, Oncorhynchus nerka, mtDNA, phylogeography, microevolution, postglacial expansion

Sockeye salmon are one of the most economically valuable species in the North Pacific. Among all the Pacific salmon it is distinguished by the most pronounced philopatry and, accordingly, the temporary stability of local populations. This biological feature significantly hinders gene flow between populations and contributes to the maintenance of sophisticated intraspecific organization. The study of current diversity formation patterns and the history of sockeye salmon populations is the key point of insight into extremely complex population structures common to pacific salmon. Phylogeography and reconstruction of paleo expansion of the species against the backdrop of global climatic oscillations in the Late Pleistocene allow us to clarify the origin of sockeye salmon populations and the diversification of intrapopulation units. MtDNA is still the marker of choice for estimation of population diversity and genetic divergence, as well as for the study of the pathways of species expansion and reconstruction of the sequence of colonization of new areas in the postglacial periods. We performed an analysis of the contemporary phylogeography of sockeye salmon and considered possible scenarios for microevolution in their Asian range using mtDNA control region (D-loop) sequencing.

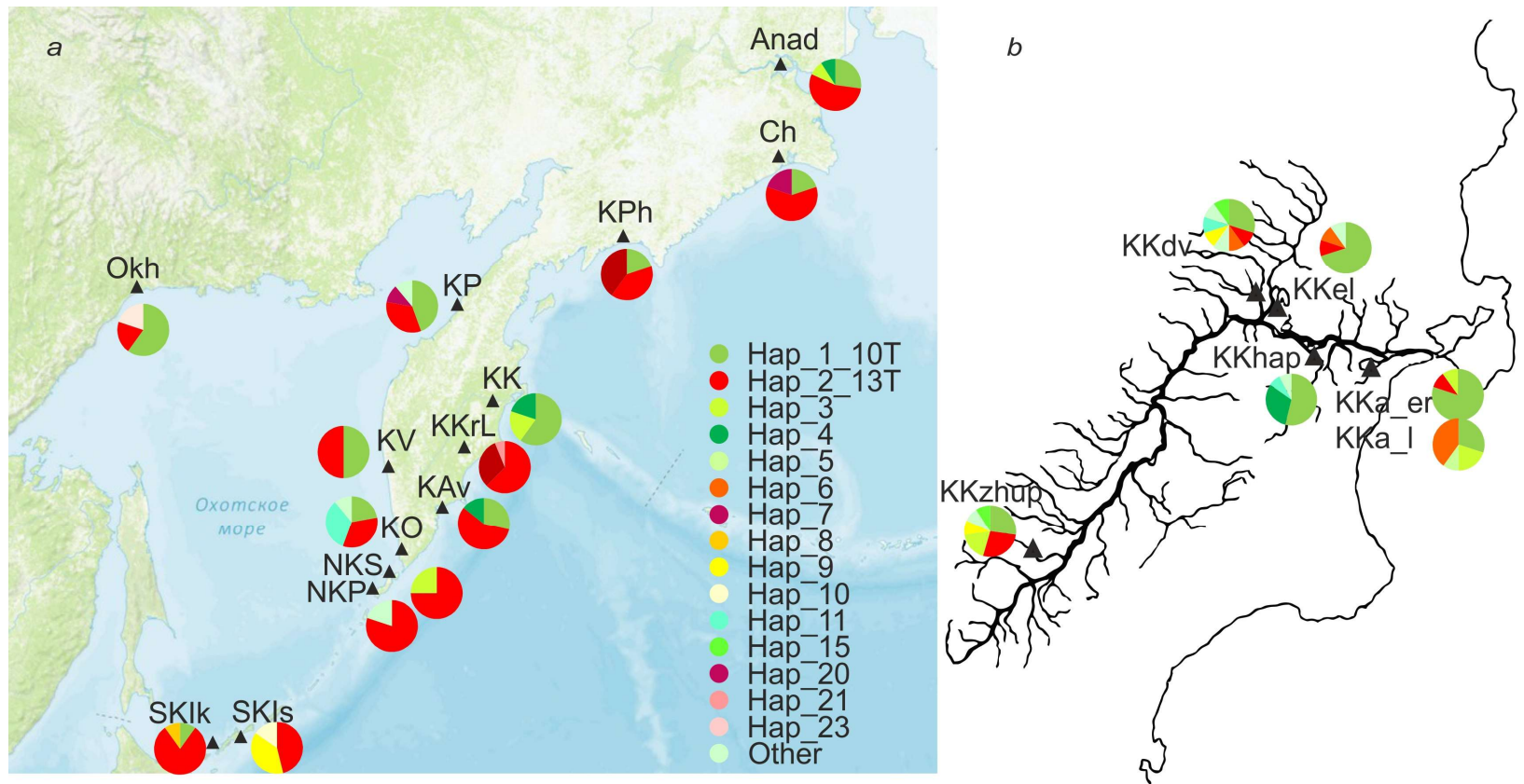

Fig. 1. Schematic map of sampling locations on the Asian Pacific coast (a) and Kamchatka River drainage (b), and haplotype frequencies in the samples. Anad-Anadyr River, $\mathrm{Ch}$-Vaamochka Lake, KPh-Pakhacha River, KK-Kamchatka River (outfall), KKa_er_-Azabachye Lake (early run), KKa_l-Azabachye Lake (late run), KKhap_Hapiza River, KKel—Elovka River, KKdv—Dvu'yurta River, KKzhup —Zhupanka River, KKrL—Kronotskoye Lake (kokanee), KAv-Avacha River, KP Palana River, KV—Vorovskaya River, KO — Ozernaya River, NKS — Shumshu Island, Bettobu Lake, NKP — Paramushir Island, Glukhoye Lake, SKIk - Iturup Island, Krasivoye Lake, SKIs - Iturup Island, Sopochnoye Lake, Okh-Okhota River. 
One hundred seventy-two sockeye salmon from 20 samples were analyzed. Fin tissue samples were collected from 2003-2017 in the watersheds of the Chukotka Autonomous Region (Chukotka), Kamchatka peninsula (Kamchatka), continental coast of the Sea of Okhotsk, and the Kuril Islands (Fig. 1). Primers HN20 and Tpro2 (Brunner et al. 2001) were used for amplification and sequencing of $1025 \mathrm{bp}$ mtDNA fragments (the entire D-loop). After multiple alignments of the sequences, 16 polymorphic sites were identified (Table 1). Most of the substitutions were detected in the first and last quarter of the D-loop sequence, as well as one insertion that was registered in the poly-T region in the middle of the sequence. Two mass haplotypes (hap_1 and hap_2) were revealed; they were present in most samples and differed by three substitutions and two indels.

Table 1. Haplotypes of the Asian sockeye salmon mtDNA control region and their nucleotide sequences.

\begin{tabular}{|c|c|}
\hline \multirow[b]{2}{*}{ Haplotype } & Substitution position \\
\hline & $\begin{array}{c}1125777889999 \\
111526239245678 \\
6151471912612278\end{array}$ \\
\hline Hap_1_10T & GTAATCC-AT- \\
\hline Hap_14 & \\
\hline Hap_13 & \\
\hline Hap_4 & \\
\hline Hap_19 & \\
\hline Hap_18 & \\
\hline Hap_15 & \\
\hline Hap_17 & \\
\hline Hap_16 & \\
\hline Hap_12 & \\
\hline Hap_5 & \\
\hline Hap_22 & \\
\hline Hap_3 & ......T. \\
\hline Hap_11 & .......T. \\
\hline Hap_9 & $\ldots . .$. \\
\hline Hap_10 & \\
\hline Hap_8 & \\
\hline Hap_20 & \\
\hline Hap_7 & \\
\hline Hap_2_13T & 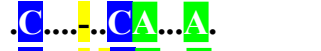 \\
\hline Hap_6 & \\
\hline Hap_23 & \\
\hline Hap_21 & - A. \\
\hline
\end{tabular}
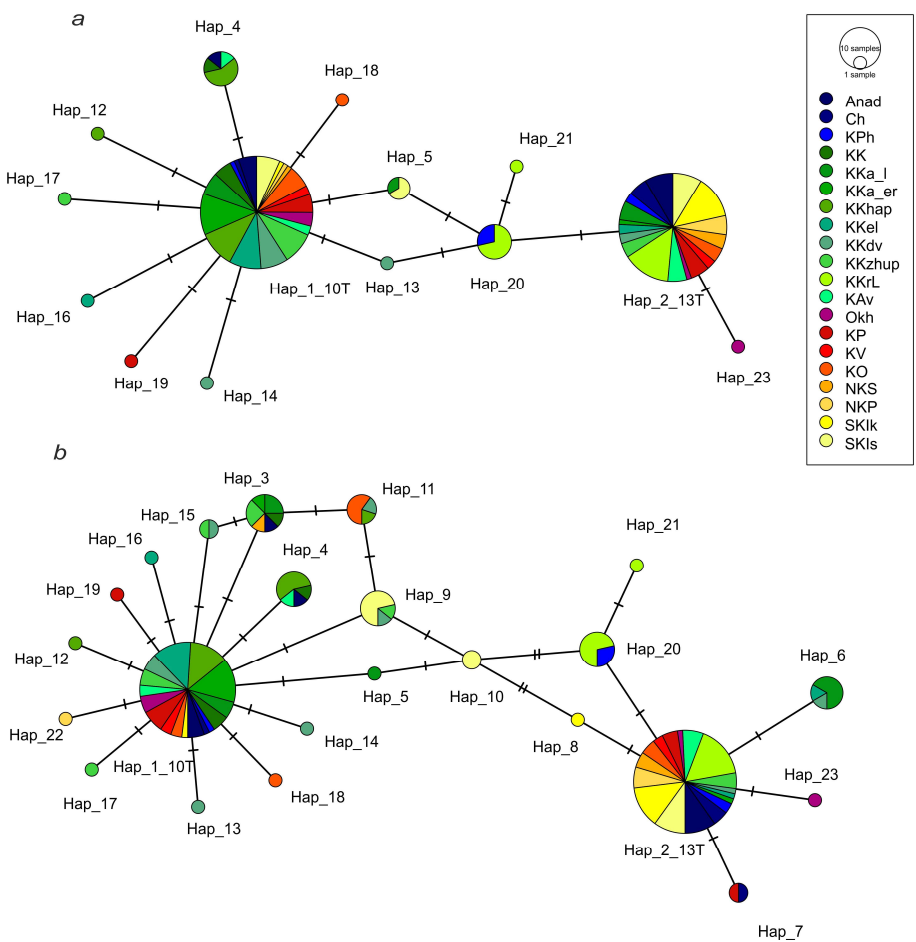

Fig. 2. Genealogical networks of sockeye salmon D-loop haplotypes, built on the base of the minimum number of nucleotide substitutions (MST-tree): a-excluding indels, $\mathrm{b}$ - including indels. The size of the circles and the area of the sectors are proportional to the frequency of the haplotype in the corresponding samples.

In the geographical distribution of the haplotypes of sockeye salmon mtDNA, some patterns can be traced (Fig. 1). Along the Asian coast of the Pacific Ocean the frequencies of the haplotypes are distributed evenly rather than a mosaic, there is no pronounced clinal character in the change in frequencies. However, the presence of both haplogroups in most populations in approximately equal proportions indicates that the entire Asian portion of sockeye range is a zone of secondary contact. The star-shaped topology of the haplotype network (Fig. 2) indicates a fast and significant increase in the diversity of groups, assuming a rapid expansion of the species after a decrease in its number due to the climatic oscillations of the Pleistocene. The genealogy of Asian sockeye D-loop haplotypes showed that all sequence variants were distributed among the two haplogroups: in the first one the central haplotype was Hap_1_10T, in the second one-Hap_2_13T; unique haplotypes differed from central ones mostly in one substitution or indel (Fig. 2). Recent demographic expansion from small founder populations was also revealed by mismatch distributions analysis (Figs. 3a, b). A good fit of both the sudden population expansion model and spatial 
expansion model was observed for both haplotypic lineages. All the results point to a rapid postglacial expansion event in the Asian part of the range. The time at which the event took place was dated by the Bayesian skyline plot analysis (Fig. 4) and indicated rapid abundance growth in the Early Holocene. In fact, during periods of the Late Pleistocene glaciations, significant areas of sockeye salmon range were covered with ice. Our results confirm the previously stated hypothesis (Brykov et al. 2005) about the relatively young historical age of most populations of Asiatic sockeye salmon, which we attributed to the beginning of the Holocene transgression ( 11,700 years ago). The exception, apparently, are sockeye salmon from the Kamchatka River basin, where in addition to the two main haplotypes, 12 derivatives were found: 11 of them belong to the first haplogroup, and one to the second (Hap_6 endemic for this basin). Certainly, the haplotypic diversity in populations that underwent cover glaciation will be less than in populations inhabiting the territories of former refugia (Hewitt 1996). We have every reason to believe that the vast paleobasin in the middle and upper reaches of the Kamchatka River (a deep lake in the Kamakovskaya Lowland and its tributaries) was one of the refugia in the Asian part of sockeye salmon range (Braitseva and Evteeva 1968), where, from the time of the Sangamon (Eemian) interglacial period (130-115 thousand years ago) and throughout the last glaciation, a large population existed.
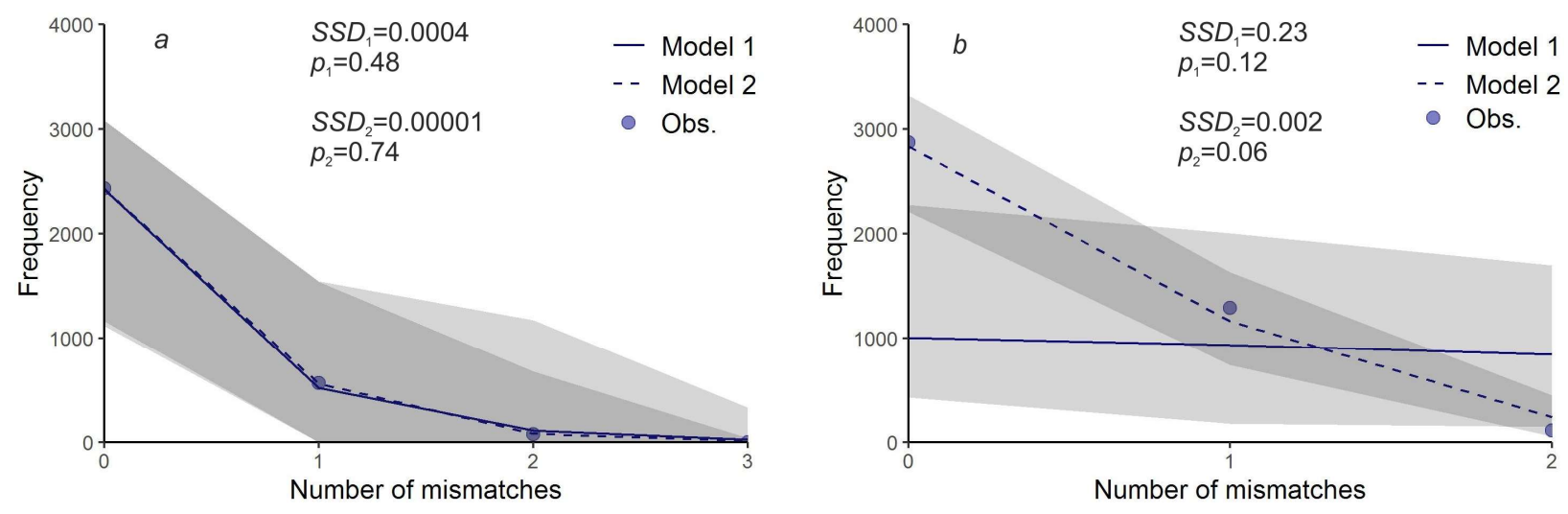

Fig. 3. Mismatch distribution analysis of the two phylogenetic lineages of sockeye salmon: a-haplogroup 1, b-haplogroup 2. The solid lines represent the expected distributions under a sudden expansion model (Model 1), the dashed line- the expected distributions under a spatial expansion model (Model 2), dots - the frequencies of the observed pairwise differences.

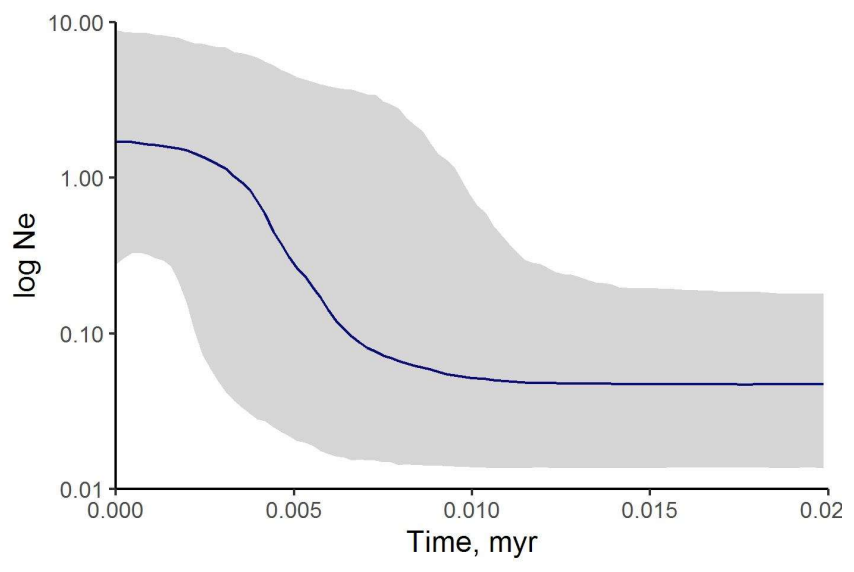

Fig. 4. Bayesian skyline plot for Asian sockeye salmon. The central bold line represents the median value for the relative effective population size, and the solid area denotes the $95 \%$ upper and lower credible limits.

Literature and our results (Brykov et al. 2005; Bachevskaya et al. 2013, 2015; Khrustaleva 2016) allow us to present a scenario of the modern diversification of sockeye salmon mtDNA haplotype formation, implying recurrent colonization of Asia by this species. The Hap_2_13T haplotype seems to have a more ancient origin (Fig. 5) associated with the American continent. The hypothesis of the North American origin of the Hap_2_13T haplotype is supported by its predominance in the sockeye salmon populations of the northwest coast of the Bering Sea (northeastern Kamchatka and Chukotka), east Kamchatka (Khrustaleva 2016), and its low polymorphism in Asian populations. It is possible the first wave of sockeye migration into Asia which followed the Middle Pleistocene, the Illinoian Stage (the Riss glaciation) (240-140 thousand years ago), led to the spread of the Hap_2_13T haplotype along the entire Asian-Pacific coast up to the northern islands of the Japanese archipelago. Most likely, the Hap_1_10T formed later, probably in Asia, because almost all transitional haplotypes (Hap_8, 9, 10) between 
haplogroups are found in the Iturup Island populations. The existence of a refugium in the Hokkaido Island region (Hokkaido and some surrounding islands) is evidenced by the presence of relict isolated populations of kokanee and freshwater ichthyofauna there and on Iturup Island (Gritsenko et al. 2012). The migration of fauna and flora of a modern composition to the southern Kuril Islands from Hokkaido Island occurred in the upper Pleistocene when there were no straits between the islands (Geologiya SSSR 1964). However, the upper Pleistocene climatic oscillations again led to fragmentation of sockeye salmon range, isolation of individual populations in several refugia, and their divergence due to local adaptation and haplotype frequency shifts under the influence of the genetic drift (population bottleneck). We suppose that the beginning of the Holocene transgression marked the extremely rapid (explosive) distribution of this species throughout their entire modern range, and watersheds were colonized simultaneously by individuals from different geographical areas, both northern (Alaska or the Beringia region) and southern (Japan and the South Kuril Islands), in parallel with the irradiation of a Hap_1_10T haplotype from the Central Kamchatka refugium. Most likely, the southernmost Asian populations (the Japanese archipelago and the South Kuril Islands), which can be considered relict, escaped secondary contact.

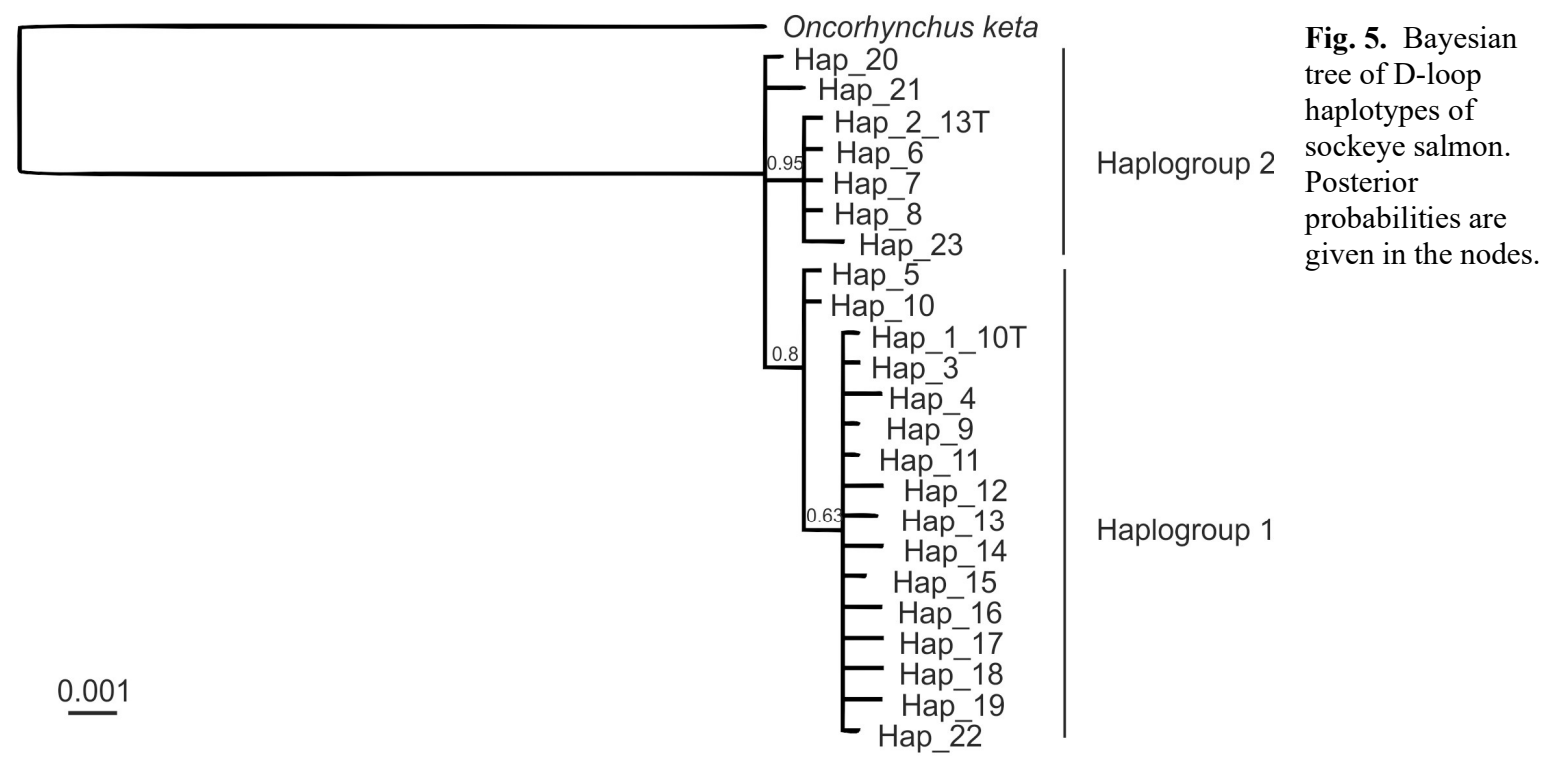

In conclusion, we would like to emphasize that our inferences are preliminary and require further experimental confirmation. However, the data obtained allow us to consider a scenario for the formation of the modern diversity of sockeye salmon mtDNA haplotypes, which implies the repeated colonization of the Asian coast by this species during the periods of sea transgression after the Pleistocene glaciations. Moreover, it is important to take into consideration the origin of Asian sockeye stocks when analyzing its population structure.

\section{REFERENCES}

Bachevskaya, L.T., V.V. Pereverzeva, and G.D. Ivanova. 2013. Variability of cytochrome $b$ gene of mitochondrial DNA in the sockeye salmon Oncorhynchus nerka Walbaum from rivers of Kamchatka and the northern coast of the Sea of Okhotsk. In Mater. 14 Mezhd. nauchn. konf. "Sokhranenie bioraznoobraziya Kamchatki i prilegayushchikh morei," Tezisy dokladov (Proc. 14 $4^{\text {th }}$ Int. Sci. Conf. "Conservation of Biodiversity of Kamchatka and Adjacent Seas," Abstracts of Papers). Petropavlovsk-Kamchatsky, Kamchatpress. pp. 40-43. (In Russian)

Bachevskaya, L.T., V.V. Pereverzeva, G.D. Ivanova, et al. 2015. Genetic diversity of sockeye salmon (Oncorhynchus nerka) from some rivers of eastern Kamchatka and continental coast of the Sea of Okhotsk according to the data on cytochrome $b$ gene polymorphism of mitochondrial DNA. Issled. Vodn. Biol. Resur. Kamchatki Sev. Zapadn. Chasti Tikhogo Okeana. 38: 49-56. (In Russian)

Braitseva, O. A., and I.S. Evteeva. 1968. Climatic fluctuations and the Pleistocene glaciations of Kamchatka. Geol. Geofiz. 5:16-22. (In Russian)

Brunner, P. C., M.R. Douglas, A. Osinov, C.C. Wilson, and L. Bernatchez. 2001. Holarctic phylogeography of Arctic charr (Salvelinus alpinus L.) inferred from mitochondrial DNA sequences. Evolution 55 (3): 573-586. 
Brykov, Vl. A., N.E. Polyakova, A.V. Podlesnykh, E.V. Golub', A.P. Golub', and O.L. Zhdanova. 2005. The effect of reproduction biotopes on the genetic differentiation of populations of sockeye salmon Oncorhynchus nerka. Russian Journal of Genetics (Genetika) 41(5): 509-517.

Geologiya SSSR, Tom 31. Kamchatka, Kuril'skiye I Komandorskiye ostrova (Geology of the Soviet Union, Vol. 31: Kamchatka, the Kuril and Commander Islands). Moscow, Nedra. 1964. pp. 734. (In Russian)

Gritsenko, O.F., K.A. Savvaitova, M.Yu. Pichugin, M.A. Gruzdeva, L.K. Sidorov, K.V. Kuzishchin, and E.V. Ponomarova. 2012. Ryby Kuril'skikh ostrovov. (Fish of the Kuril Islands). Moscow, VNIRO Publishing House. 978 pp. (In Russian)

Hewitt, G. M. 1996. Some genetic consequences of ice ages, and their role in divergence and speciation. Biol. J. Linn. Soc. 58: 247-276.

Khrustaleva, A.M. 2016. The phylogeography of the Asian sockeye salmon Oncorhynchus nerka, inferred from the data on the variability of mitochondrial SNP loci: analysis of scenarios for post-glacial expansion of the species over the Asian Coast of the Pacific Ocean. Russ. J. Mar. Biol. 42(7): 517-526. 